\title{
The Effect of Increasing Mechanic Competence via Competence-Based Curriculum on Product Support Performance in Leading Indonesian Heavy Equipment Manufacturers
}

\author{
Sofyan $^{2}$ \\ ${ }^{1}$ United Tractors. Tbk., Jakarta - Indonesia \\ ${ }^{2}$ Master of Mechanical Engineering Swiss German University, Tangerang - Indonesia \\ *Corresponding author. Email: dena.hendriana@sgu.ac.id
}

Teguh Setiono ${ }^{1,2}$ Dena Hendriana ${ }^{2, *}$ Henry Nasution $^{2}$ Gembong Baskoro ${ }^{2}$ Edi

\begin{abstract}
The amount of product support determines the availability and readiness of heavy equipment. Product support as after-sales service is essential for customers to ensure that the heavy equipment purchased is always ready to use and generates optimal output. Leadtime and mechanic speed in resolving equipment problems and the so-called On Time in Full Solution (OTIF Solution) impact the usability and productivity of the equipment. Product Support Performance is affected by the OTIF Solution, which in turn influences customer satisfaction. The development of mechanic competencies through competency-based training and problems in the field regarding the Special Work Competency Standards is a technique to strengthen mechanics' ability and speed to solve machine problems to achieve good OTIF Solution performance. The purpose of this study is to determine the impact of improving competence. Mechanic via product performance support training with competency-based curriculum Teaching machines carried out this study with poor OTIF Solution performance using the blended learning method and training modules. The findings revealed that once mechanics were trained, the OTIF Solution increased from the previous two years. Specifically, 89 and $88 \%$ fell short of the planned range of 90 to $93 \%$.
\end{abstract}

Keywords: Product Support, Competency Based Curriculum, Specific Work Competency Standards, Training Need Analysis, Blended Learning.

\section{INTRODUCTION}

Heavy equipment is a large size machine and can do serious work such as earthmoving, coal moving. Common types of rich prayers are bulldozers, excavators, wheel loaders, motor graders and heavy dump trucks.

The heavy equipment population is spread across four sectors, namely Forestry, Mining, Construction and Agro. According to data released by one of the Komatsu heavy equipment distributors in Indonesia, Komatsu heavy equipment sales volume from 2014 to 2019 reached 19,411 units of heavy equipment [1].

Competition in heavy equipment sales to dominate the market is very tight. Each distributor will maintain and even increase market share with a pricing strategy and a product support strategy.

Customers as owners of heavy equipment certainly expect their heavy equipment to always be in a good performance and highly efficient so that their heavy equipment can produce optimal production.

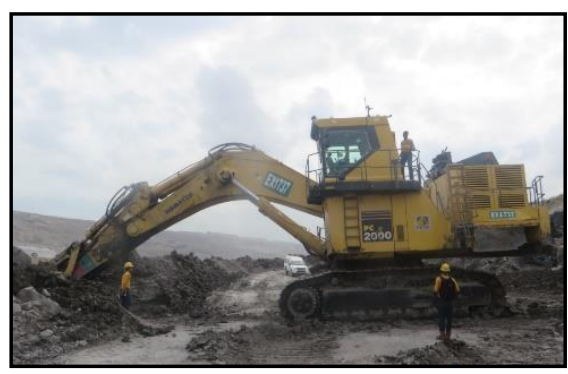

Figure 1 Mechanics handling an Excavator that was damaged while operating in the field

For distributors who are leaders in the market, increasing product support is an essential strategy. Leadtime and mechanic speed in solving problems that occur in equipment and the so-called On Time in Full Solution (OTIF solution) affect the equipment's usability and productivity. Performance OTIF solution 
affects Product Support Performance, and this affects the level of customer satisfaction. Figure 1 shows several Mechanics handling heavy equipment that was damaged while operating in the field.

The achievement of the OTIF solution is shown in Figure 2, the target so that the customer is not satisfied with the mechanic's ability to identify the problem and service result quality [1].

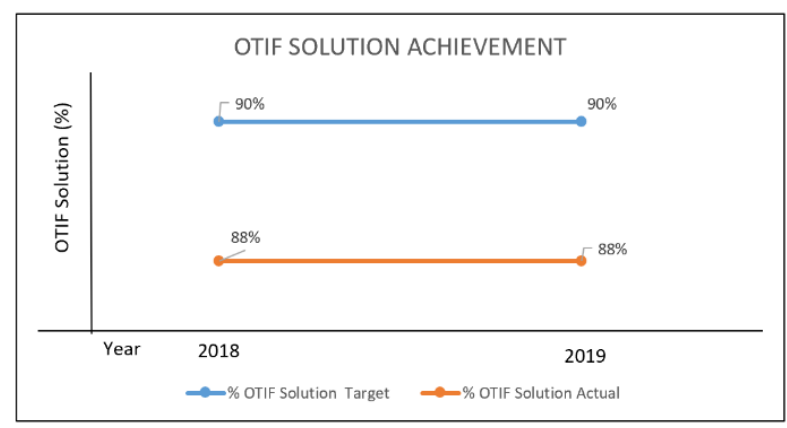

Figure 2 OTIF solution achievement

The readiness of mechanics who have reliable technical skills and knowledge is part of improving product support performance. For this reason, mechanic training is needed following operational needs and training programs that can enhance mechanic competence [2-3].

Training is an essential component in the development of human resources (HR) in an institution to improve the knowledge, skills and positive attitude of human resources to improve the performance of institutions in the face of change and external competition [4].

Training programs can be interpreted as learning experiences that focus on individual efforts to obtain specific skills that can be immediately used.

A training program that is carried out effectively and efficiently will positively contribute to the development and progress of the company. Therefore, the training carried out must be following training need analysis [5$6]$.

An effective and efficient training program will positively contribute to the development and progress of the company. Therefore, the training must follow the training needs analysis and a competency-based curriculum [7-8].

The first step in creating a competency-based curriculum is to identify these problems in handling machine problems taken from trouble machine data to be analysed so what competencies the mechanic needs to get the job done. The next step is to use the competency requirements to make a training needs analysis and create a competency-based curriculum.

\section{METHODOLOGY}

\subsection{Training Need Analysis and Competency Requirement}

Mechanic competency development activities begin with a Training Need Analysis following the operational needs of mechanic abilities. The gap between current mechanic abilities and required mechanic abilities may indicate a problem that can translate into training needs. The condition for mechanic competence is reflected in the achievement of the OTIF solution.

Figure 3 show the machine problem data, and the OTIF solution per machine, both the problem and the OTIF solution for Excavator machines are the biggest problems with 1371 problem. The OTIF solution machine excavator has only been achieved $88 \%$ [1].

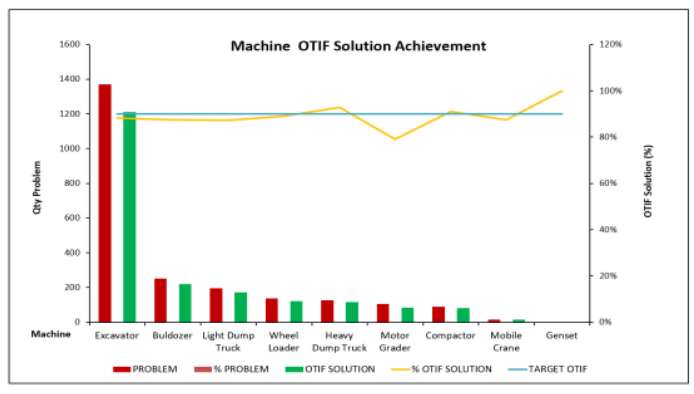

Figure 3 Machine OTIF solution achievement

The machine Problem and OTIF solution data are focused on Machine Excavator for the mechanic's development pilot project. There are nine components and systems used as a reference for measuring the OTIF solution machine in the excavator machine. Each element and method is also measured how much the OTIF solution has achieved. There are three main components and systems for excavators, namely Engine, Hydraulic and Electric is shown in Figure 4 [9-10].

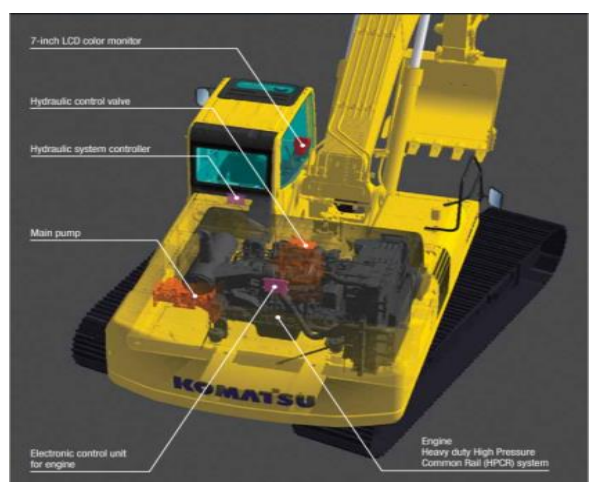

Figure 4 Component and system excavator

From the data on machine system problems and OTIF Solution components on the excavator for OTIF Solution performance in Figure 5, the three parts and systems, namely Engine, Hydraulic and Electrical, are in bad condition. Henceforth, the three competencies will be detailed in specific work competencies. So that 
for the development of competency mechanics on machine excavators that will become a pilot project, namely:

1. Troubleshooting engine control system excavator.

2. Troubleshooting hydraulic control system excavator.

3. Troubleshooting electrical control system excavator.

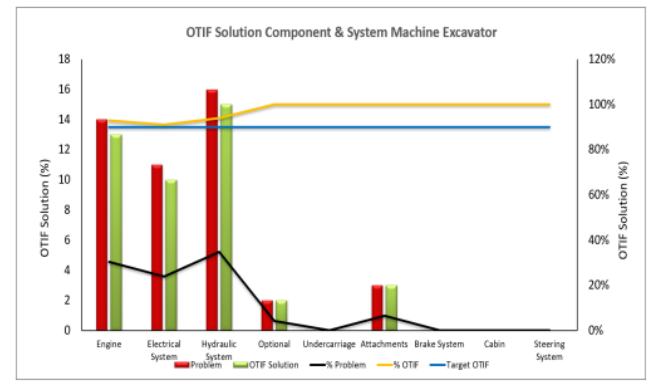

Figure 5 OTIF solution component excavator

\subsection{Training Program and Development}

\subsubsection{Specific Work Competency Standards}

Specific work competency standards are competency standards developed and used by organizations to meet their internal organizational goals and meet the needs of other organizations that have a cooperative relationship with the organization concerned. The development of particular work competency standards is based on the need to fulfil the mechanic's competency development activities for the operational needs of the mechanic's abilities as outlined in the training needs analysis. Specific work competency standards may consist of one or several competency units.

Table 1. Matrix of specific work competency standards for trouble shooting engine control system excavator

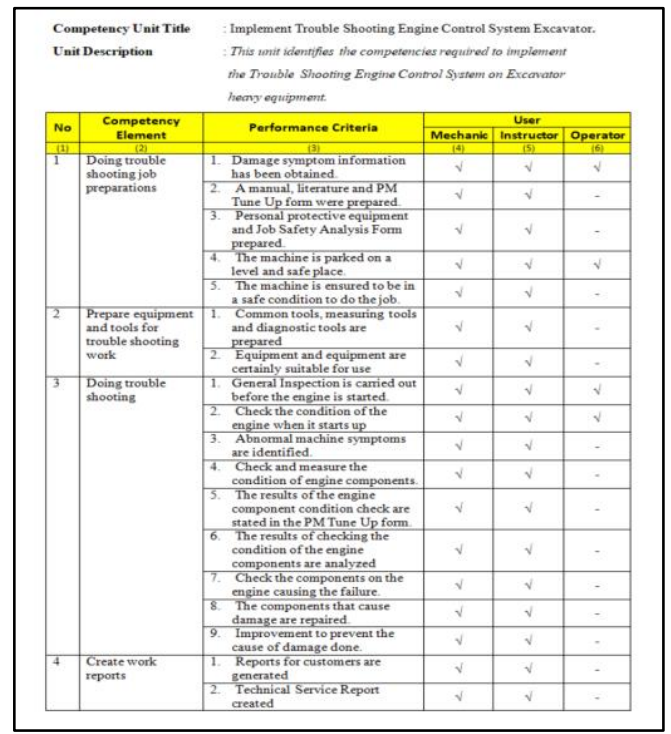

One example of a specific work competency standard is seen in Table 1, where there are four competency elements, namely making troubleshooting job preparation, prepare equipment and tools for troubleshooting work, making trouble shooting and create work reports. Each competency element in the specific work competency standard will be detailed in performance criteria and user positions that match those competencies [1].

\subsubsection{Curriculum and Syllabus}

The Curriculum is structured based on competency elements and performance criteria that have been made in specific work competency standards by providing more detailed indicators of the success of each performance criterion and the time needed to study, which in turn can determine the training modules required is shown in Table 2 [8].

Table 2. Training curriculum structure matrix

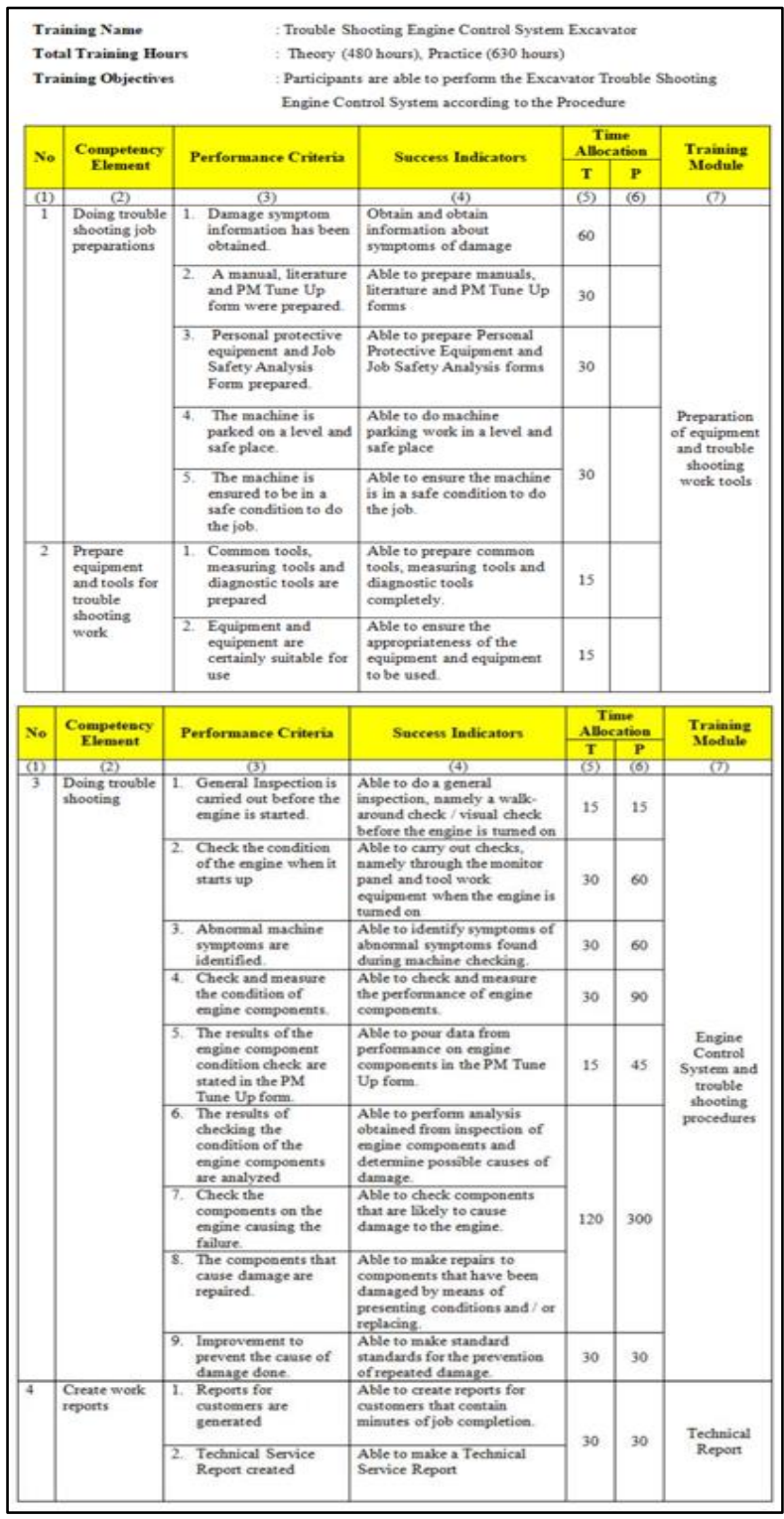


The syllabus is a learning plan for a particular group of training subjects, including competency standards, descriptions of training subjects, essential competencies, performance criteria, performance indicators, training materials, assessments, methods, time allocation and information sources are shown in Table 3.

Table 3. Training syllabus preparation of equipment and troubleshooting work tools

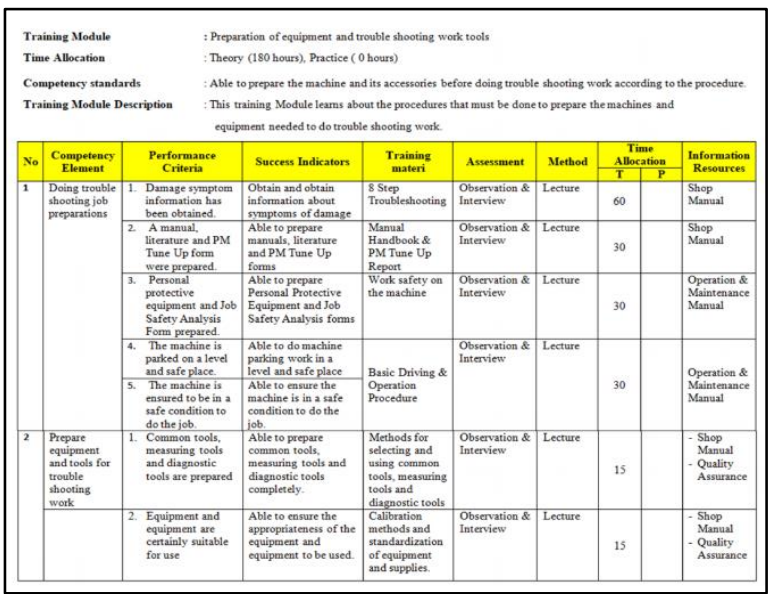

\subsubsection{Blended Learning}

For mechanic development programs using Blended Learning, a method is shown in Figure 6. To implement the blended learning program supported by the United Tractors Learning Management System (UT LMS) infrastructure with the name "TOP UP". United Tractors Learning Management System (UT LMS) is a software application for activities in the network, electronic learning programs (e-learning programs), distributing training materials and enabling collaboration between mechanics and instructors. UT LMS can manage every aspect of the training, from registering participants to storing test results.

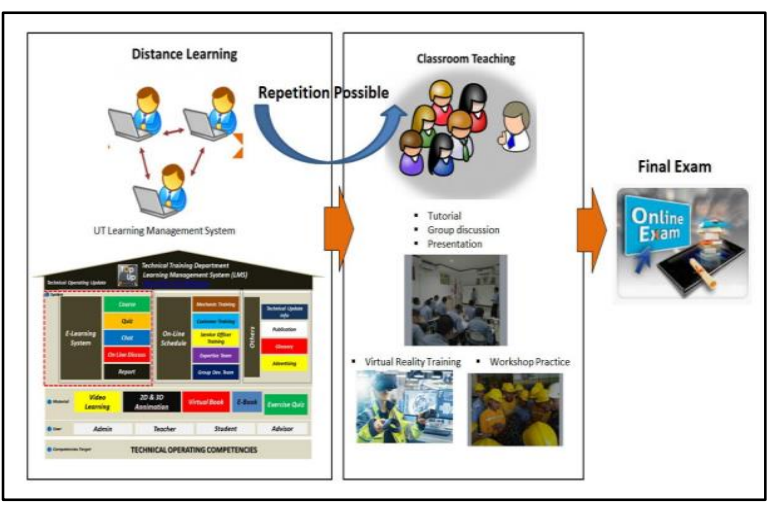

Figure 6 Structure of blended learning

According to the schedule, administrators will register Participants and Course Instructors in the UT Learning Management System called "Top Up" according to the program.

\section{RESULTS AND DISCUSSIONS}

To determine the mechanics and branches that will be given training, it is determined based on the performance of the OTIF solution where the branch with the Bad category of OTIF solution performance becomes a priority for technical development.

Table 4 shows the 11 (eleven) branches that have OTIF solution performance in the "Bad" category, namely Pakanbaru, Surabaya, Padang, Makassar, Sampit, Tarakan, Pontianak, Manado, Jambi, Bandar Lampung and Palu with a total mechanic of 130 people.

Table 4. OTIF solution machine excavator per branch vs number of mechanic and machine

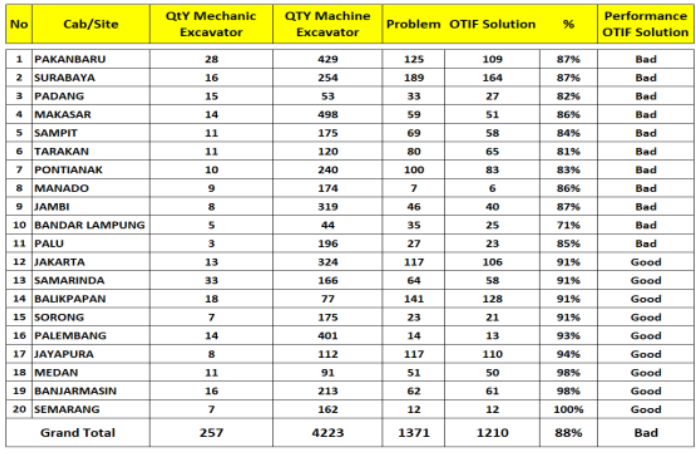

The training is carried out using the blended learning method, where the mechanic will train online. Then after the online training, it is continued with tutorials and on-machine practice. Tutorials are conducted online and shown in class with a discussion method facilitated by an instructor [11]. This tutorial event is also a place for sharing mechanics experiences to increase knowledge and skills knowledge among mechanics. After deepening the material through tutorials, with the guidance of an instructor, the training is continued with hands-on practice at the machine excavator to ensure troubleshooting is carried out with the correct procedures, both regarding the procedures for using tools and techniques for solving problems. In this practical training, the mechanic will also try to solve a troubleshooting case study based on the trouble that often occurs in operation and also the trouble simulated by the instructor, which can be detected from the error code on the monitor panel.

\subsection{Training Achievement}

All mechanics have carried out online training and tutorials in eleven branches for three training modules, namely the engine control system, hydraulic control system and electric control system, to achieve training coverage of $100 \%$.

Table 5 shows the engine control System module all $100 \%$ of mechanics passed with the passed training category, the hydraulic control system passed with the given training category of $99.2 \%$ or 129 mechanics from 
130 mechanics and the electric control system passed with $95.4 \%$ passed training categories or 124 mechanics from 130 mechanics.

Table 5. Mechanic training coverage

\begin{tabular}{|c|c|c|c|c|c|c|c|c|}
\hline \multirow{3}{*}{ No } & \multirow{3}{*}{ Cab/Site } & \multicolumn{7}{|c|}{ Participants vs Module } \\
\hline & & \multirow{2}{*}{$\begin{array}{l}\text { Mechanic } \\
\text { Plan }\end{array}$} & \multicolumn{2}{|c|}{$\begin{array}{l}\text { Engien Control } \\
\text { System }\end{array}$} & \multicolumn{2}{|c|}{$\begin{array}{l}\text { Hydraulic Control } \\
\text { System }\end{array}$} & \multicolumn{2}{|c|}{$\begin{array}{l}\text { Electric Control } \\
\text { System }\end{array}$} \\
\hline & & & Actual & $\%$ & Actual & $\%$ & Actual & $\%$ \\
\hline & PADANG & 15 & 15 & $100 \%$ & 15 & $100 \%$ & 15 & $100 \%$ \\
\hline 2 & SAMPIT & 11 & 11 & & 11 & & 11 & $100 \%$ \\
\hline 3 & PONTIANAK & 10 & 10 & $100 \%$ & 10 & $100 \%$ & 10 & $100 \%$ \\
\hline 48 & BANDAR LAMPUNG & 5 & 5 & $100 \%$ & 5 & $100 \%$ & 5 & $100 \%$ \\
\hline 5 p & PAKANBARU & 28 & 28 & $100 \%$ & 28 & $100 \%$ & 28 & $100 \%$ \\
\hline & JAMBI & 8 & 8 & $100 \%$ & 8 & $100 \%$ & 8 & $100 \%$ \\
\hline & MANADO & 9 & 9 & $100 \%$ & 9 & $100 \%$ & 9 & $100 \%$ \\
\hline $8 \mathrm{~T}$ & TARAKAN & 11 & 11 & $100 \%$ & 11 & $100 \%$ & 11 & $100 \%$ \\
\hline $9 \mathrm{~s}$ & SURABAYA & 16 & 16 & $100 \%$ & 16 & $100 \%$ & 16 & $100 \%$ \\
\hline $10 \mathrm{P}$ & PALU & 3 & 3 & $100 \%$ & 3 & $100 \%$ & 3 & $100 \%$ \\
\hline & MAKASAR & 14 & 14 & $100 \%$ & 14 & $100 \%$ & 14 & $100 \%$ \\
\hline & TOTAL & 130 & 130 & $100 \%$ & 130 & $100 \%$ & 130 & $100 \%$ \\
\hline
\end{tabular}

Figure 7 shows the theory test results provide an overview of all mechanics as training participants who have conducted online theory tests. Mechanics that are declared passed training are mechanics that get a score above 80. In contrast, mechanics who earn a score below 80 are reported not to pass and will be given the opportunity to remedial once with a value above 80 , later categorized as passed by corrective.

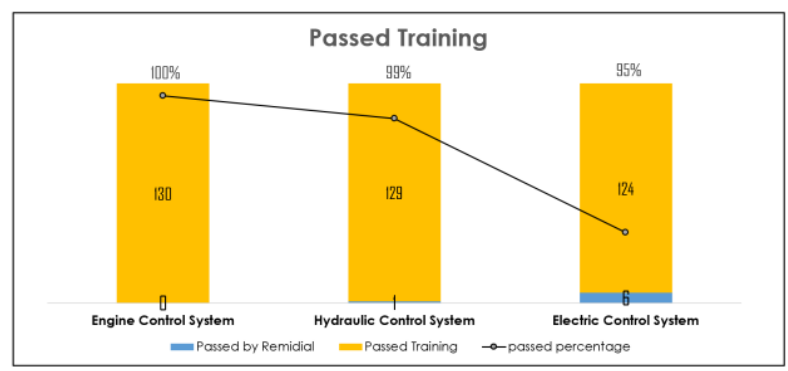

Figure 7 Theory test results

The practical implementation test is carried out directly on the machine excavator and is tested one by one by the trainees by an instructor.

Table 5 shows the practical test results were obtained for three competencies, namely engine control system, hydraulic control system and electrical control system in Good3 position, meaning that proven mechanics can perform troubleshooting well and correctly starting from preparing to solve the problem to the problem is resolved and can be included in technical reports.

Table 6. Trouble shooting assessment skill test result

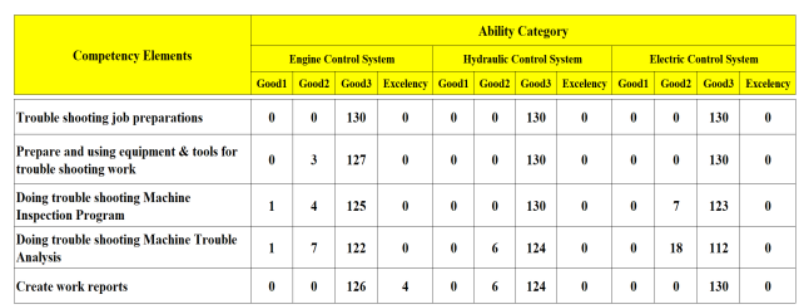

\subsection{Training Program Evaluation}

To evaluate whether the program has accommodated the need for increased competency mechanics and the implementation of this program is going well, it is necessary to get input from mechanics as training participants to create a mechanic questionnaire, as shown in Table 7.

Table 7. Mechanic questionnaire result

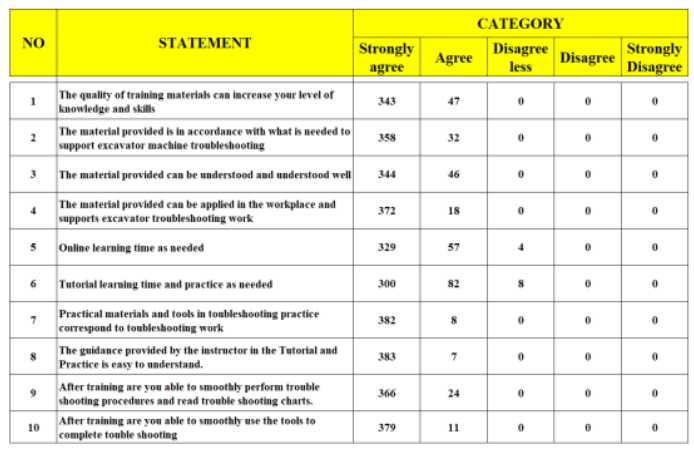

The input of 130 mechanics as responders stated that the program was following the needs of increasing mechanical competence and implementing the program following the mechanic's requirements. As reflected in the majority of respondents said strongly agree and agree. Four responders gave disagree less input at the time allocated for the online learning implementation, and eight respondents gave disagree less information during the tutorial and practical implementation.

To evaluate the program as a whole, starting from the specific work competency standards to whether the curriculum is made, whether it accommodates the need for increasing mechanical competence, and the implementation of this program is running well, it is necessary to get input from the instructor as a teacher in training so that an Instructor Questionnaire is made, as shown in Table 8.

Table 8. Training instructors questionnaire result

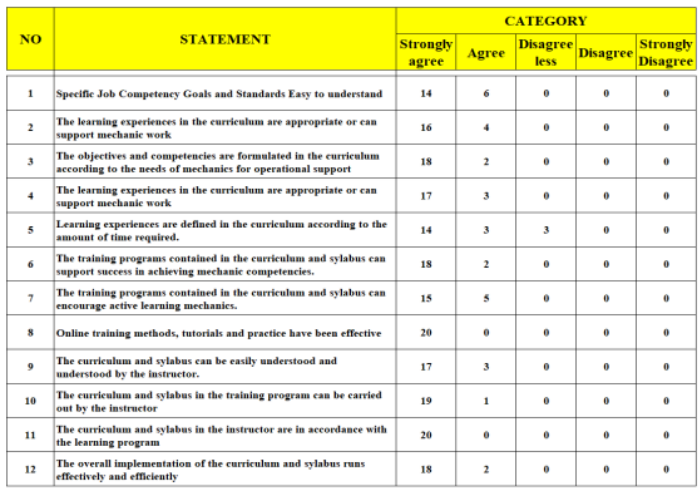

Of the 20 instructors who taught in this program assessed that the program could be implemented well in increasing mechanic competence according to operational needs. Reflected in the questionnaire results, 
most of them stated strongly agree and agree with each statement on the questionnaire.

After the mechanic gets training on the machine excavator, every time there is a problem with the excavator machine, to solve the problem, priority is given to mechanics who have received this training intending to know the increase in mechanical competence have received training in problem-solving and also to improve the performance of the excavator's OTIF solution machine. From the data taken from the HEAT System (Helpdesk Expert Automation Tools) after the mechanic received training on November 9, 2020, to December 10, 2020, 46 problems occurred and were resolved with the appropriate time as many as 43 problems so that the OTIF solution achievement was $93 \%$. Details of the number of the issues and OTIF Solution per component and system can be seen in the OTIF solution achievement Table 9.

Table 9. OTIF solution achievement

\begin{tabular}{|c|c|c|c|c|c|c|}
\hline \multirow{3}{*}{ No } & \multirow{3}{*}{$\begin{array}{c}\text { Component \& } \\
\text { System }\end{array}$} & \multicolumn{4}{|c|}{2020 (One Month) } & \multirow{3}{*}{$\begin{array}{l}\text { Performance OTIF } \\
\text { Solution }\end{array}$} \\
\hline & & \multicolumn{2}{|c|}{ Problem } & \multicolumn{2}{|c|}{ OTIF Solution } & \\
\hline & & Qty & $\%$ & Qty & $\%$ & \\
\hline 1 & Engine & 14 & $30 \%$ & 13 & $\mathbf{9 3 \%}$ & Good \\
\hline 2 & Electrical System & 11 & $24 \%$ & 10 & $91 \%$ & Good \\
\hline 3 & Hydraulic System & 16 & $35 \%$ & 15 & $94 \%$ & Good \\
\hline 4 & Optional & 2 & $4 \%$ & 2 & $100 \%$ & Good \\
\hline 5 & Undercarriage & 0 & $0 \%$ & 0 & $0 \%$ & \\
\hline 6 & Attachments & 3 & $7 \%$ & 3 & $100 \%$ & Good \\
\hline 7 & Brake System & 0 & $0.0 \%$ & 0 & $0 \%$ & \\
\hline 9 & Cabin & 0 & $0.0 \%$ & 0 & $0 \%$ & \\
\hline 8 & Steering System & 0 & $0.0 \%$ & 0 & $0 \%$ & \\
\hline & Grand Total & 46 & $100 \%$ & 43 & $93 \%$ & Good \\
\hline
\end{tabular}

The results also show that the development of a mechanic competence with a competency-based curriculum impacts improving product support performance, significantly increasing the performance of OTIF solutions. Figure 8 is a reflected that there has been an increase in OTIF solution above the $90 \%$ target for components and systems for the engine control system, hydraulic control system and electric control system on machine excavators so that the excavator's OTIF solution machine has increased from $89 \%$ in 2018 and $88 \%$ in 2019 to $93 \%$ in 2020 .

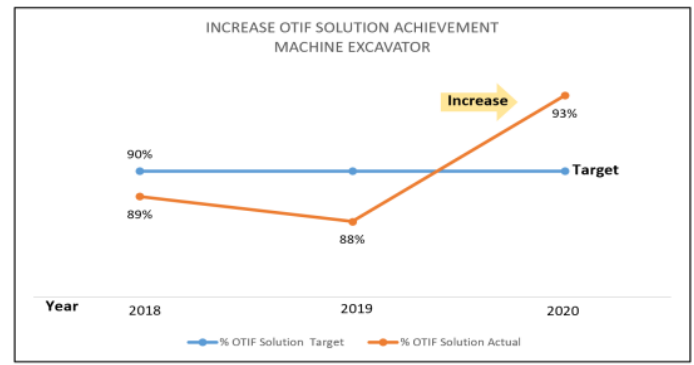

Figure 8 Increase OTIF solution achievement on excavator

\section{CONCLUSIONS AND FURTHER IMPROVEMENT}

\subsection{Conclusions}

a. The research results show that the development of mechanic competence through competency-based training and problems in the field can increase the ability and speed of mechanics to solve problems that occur in machines. The knowledge and speed of mechanics to solve machine problems will affect the performance of OTIF solutions. The more issues that are resolved from problems that occur in the machine and the completion time is below the specified time standard, and the OTIF solution performance will be good. Conversely, the more problems are resolved, but the time to solve them is above the specified time standard, the OTIF solution performance will be wrong. A good performance of the OTIF solution reflects good product support performance and vice versa.

b. The research results that have been carried out show that the development of mechanics that refers to the competency standards for particular work and pour in more detail into a competency-based curriculum can align training programs. Competency needs to be required in operations.

c. The research results that have been carried out show that the development of mechanics using the blended learning method, namely mechanic learning independently through online and tutorials containing discussions and direct practice in machines with the guidance of an instructor, is an effective learning method.

\subsection{Further Improvement}

From the research that has been done, several things need to be further improved and developed to obtain more accurate data and testing of a mechanic competency development program with a competencybased curriculum to increase the performance of the OTIF solution. The following are some recommendations that can be made to optimize this research:

a. To get the accuracy of the relationship between the improvement of mechanic competence and the performance of the OTIF solution, the OTIF solution data is more accurate if taken at least within six months to obtain OTIF solution data from more problem machines.

b. To obtain a more precise training program and following the need for increasing mechanical competence, the preparation of specific work 
competency standards, curriculum and syllabus is carried out in collaboration with experts in each machine such as Instructors, Technical Consultants, Quality Assurance and Senior Mechanics.

c. Training with the blended learning method can be carried out in other training modules to accelerate the improvement of mechanic competence across branches by adding time to tutorial and practice sessions.

\section{AUTHORS' CONTRIBUTIONS}

Teguh Setiono made contributions as first authors. Data was collected and analysed by Teguh Setiono and Dena Hendriana. All authors (Henry Nasution, Gembong Baskoro, and Edi Sofyan) made contributions to the design of the study and the writing of the manuscript.

\section{ACKNOWLEDGMENTS}

I Want to thank Mr Edi Sofyan, B.Eng, M.Eng, PhD and Mr Dena Hendriana B.Sc, S.M., Sc.D and all Lecturers who have guided me while studying at Swiss German University. And also, to Mr Edhie Sarwono and Mr Idot Supriadiand, PT United Tractors Tbk's management allowed me to take a Master's degree.

\section{REFERENCES}

[1] United Tractors, Book of Mechanic, Jakarta: United Tractor, 2016.

[2] E. Mulyasa, Kurikulum Berbasis Kompetensi, Konsep, Karakteristik, dan Implementasi, Bandung: Remaja Rosdakarya, 2006.

[3] B. A. Pribadi, Desain dan Pengembangan Program Pelatihan Berbasis Kompetensi, Jakarta: Prenadamedia Group, 2014.

[4] P. L. Smith, and T.L. Ragan, Instructional Design, New York: Wiley Jossey-Bass Education, 2007.

[5] J. Barbazette, Training Need Assessment: Methods, Tools and Technniques. San Francisco: John Wiley, 2006.

[6] P. Donovan and J. Townsend, The Training Need Analysia Pocketbook, United Kingdom: Management Pocketbooks Ltd, 2005.

[7] P. Boahin and P. Boahin, Competency Based Curriculum: A framework for Building Assessment and the world of work, International Journal of Vocational and Technical Education Research, Vol.4, No.2, May 2018, pp.1-15.

[8] J. Kim, Competency-based Curriculum: An Effective Approach to Digital Curation Education,
J. of Education for Library and Information Science, Vol. 56(4), October 2015, pp.283-297. doi:10.12783/issn.2328-2967/56/4/2.

[9] S. Haryadi, D. Hendriana, H. Nasution, G. Baskoro," Monitoring of Thermostat Performance in Heavy Equipment Diesel Engine Cooling System Using an Ultrasonic Flow Meter, 2 ${ }^{\text {nd }}$ Proceedings of The Conference on Management and Engineering in Industry (CMEI 2020), Vol. 2, pp. 1-6, Tangerang, Indonesia, September 2020.

[10] S. Sadono, C.S.A. Nandar, D. Hendriana, H. Nasution, G. Baskoro. Modeling, Simulation, and Analysis of Auto Warming Up and Overheat Prevention System in Komatsu Hydraulic Excavator PC 200-8, 2 $2^{\text {nd }}$ Proceedings of The Conference on Management and Engineering in Industry (CMEI 2020), Vol. 2, pp. 1-6, Tangerang, Indonesia, September 2020.

[11] L. Vanderkam, Blended Learning, Washington: The Philanthropy Roundtable, 2013. 